Vol. 6 (1997): 25-36.

\title{
Universally primed polymerase chain reaction analysis of Fusarium avenaceum isolated from wheat and barley in Finland
}

\author{
Tapani Yli-Mattila \\ Laboratory of Plant Physiology and Plant Molecular Biology, Department of Biology, FIN-20014 University of \\ Turku, Finland, e-mail: tymat@utu.fi \\ Nina V. Mironenko \\ All-Russian Plant Protection Institute, Laboratory of Plant Immunity to the Pests, St. Petersburg 189620, Russia \\ Irina A. Alekhina \\ Komarov Botanical Institute, Laboratory of Fungal Biochemistry, St. Petersburg 197376, Russia \\ Asko Hannukkala \\ Institute of Plant Protection, Agricultural Research Centre of Finland, FIN-31600 Jokioinen, Finland
}

Sergey A. Bulat

Petersburg Nuclear Physics Institute (PNPI), Department of Molecular and Radiation Biophysics, Gatchina 188350, Russia

\begin{abstract}
Twenty-two Fusarium avenaceum isolates from Finnish wheat and barley were analysed using the chain reaction with universal primers (UP-PCR). Each isolate could be distinguished from others by UP-PCR products on polyacrylamide gels. The isolates tested were clustered into two main groups and further into several subgroups by UP-PCR profiles and phylogenetic analyses. The phylogenetic relationships of these groups are discussed. No clear correlation was found between the groups and host plant preference or the geographic origin of $F$. avenaceum isolates. Pathogenicity tests showed differences between $F$. avenaceum isolates, but two isolates, one from wheat and the other from barley, were the most aggressive in wheat and barley. This fungus, usually known as a weak pathogen of cereals and other crops, has thus probably not evolved in respect to its ability to damage wheat or barley.
\end{abstract}

Key words: Gibberella avenacea, identification, genotyping, parsimony analysis, UP-PCR

\section{Introduction}

Fusarium avenaceum (Fr.) Sacc. can be regarded as a weak pathogen. Under conditions unfavourable to its hosts, it may cause damping off, root rot, stalk rot and/or fruit rot (Gerlach and Nirenberg 1982). The sexual state (teleomorph) of $F$. avenaceum, called Gibberella avenacea (Booth 1971), is quite rare in nature (Booth and Spooner 1984) and has never been reported from Finland. 


\section{AGRICULTURAL AND FOOD SCIENCE IN FINLAND}

\section{Yli-Mattila, T. et al. UP-PCR analysis of Fusarium avenaceum isolated from wheat and barley}

In Finland, Fusarium avenaceum is a common inhabitant of living and dead organic substrates (Ylimäki and Jamalainen 1986). It is frequently found on cereal grain, where it causes seedling blight and has potential for mycotoxin production (Ylimäki 1981). Together with other Fusarium species, F. avenaceum is associated with foot and root rot diseases of all cereals grown in Finland (Mäkelä and Parikka 1980). It is considered less destructive than F. culmorum, but a wide range of variation in pathogenicity between isolates has been reported by Uoti (1976). F. avenaceum has also caused considerable storage losses in potato (Seppänen 1981a).

Like those of $F$. oxysporum, $F$. avenaceum isolates are very difficult to distinguish from each other on the basis of morphological or physiological characters. F. avenaceum isolates have been grouped into three main types by isozyme analysis (Yli-Mattila et al. 1996). Restriction fragment length polymorphism (RFLP) (Nicholson et al. 1993) and random amplified polymorphic DNA polymerase chain reaction (RAPDPCR) analyses (Yli-Mattila et al. 1996, Yli-Mattila and Hyvönen 1996) yielded a higher resolution than isozyme analysis, making it possible to distinguish nearly all $F$. avenaceum isolates from one another.

In the present study the less familiar polymerase chain reaction with universal primers (Universally Primed Polymerase Chain Reaction UP-PCR) was used (Bulat et al. 1992, Bulat et al. 1994, Naumov et al. 1997). The main difference between UP-PCR and RAPD-PCR (Williams et al. 1990) and arbitrarily primed PCR (AP-PCR) (Welsh and McClelland 1990) is that the single primers of UP-PCR (ca 16 nucleotides) consist of random 3' end and "natural" minisatellite-like sequences (which can be found in any genome) at the 5' end, which along with a specific PCR protocol using Tsp polymerase as well as high ramping thermal cycler, makes it less sensitive to reaction conditions (minor changes in annealing temperature, $\mathrm{Mg}^{2+}$ concentration etc.) than AP- PCR and RAPD-PCR. The primer extention at the 5' end by minisatellite-like sequence makes the primer hybridization more stable. UP-PCR banding patterns are fully reproducible, even between different cyclers, provided that exactly the same protocol including ramping rate is used (S.A. Bulat, unpublished data).

The purpose of the present study was to assess identification and phylogenetic relationships in $F$. avenaceum isolated from wheat and barley in Finland. The UP-PCR technique was employed to test the correlation between the genome structure of the isolates and their host preference. Such a correlation has previously been demonstrated for the fungus Cochliobolus sativus (anamorph Bipolaris sorokiniana), which is also a pathogen of wheat and barley and of which the sexual stage is rare in nature (Bulat and Mironenko 1993). Another objective was to compare the isolate relationships obtained here with those obtained previously by RAPD-PCR analysis (Yli-Mattila et al. 1996, Yli-Mattila and Hyvönen 1996). In addition, the species uniqueness of $F$. avenaceum at the genome level as compared with other Fusarium fungi was studied by means of cross dot blot hybridization of UP-PCR products. Preliminary results of UP-PCR analysis have been presented (Yli-Mattila et al. 1997).

\section{Material and methods}

\section{Fungal isolates, growth conditions and DNA extraction}

Twenty-three isolates of Fusarium avenaceum and six isolates from other Fusarium species were isolated from barley, wheat or oats collected in different locations in Finland (Table 1, Fig. 1) as described by Yli-Mattila et al. (1996, 1997). Each isolate was grown for 4-7 days on a cellophane membrane on the surface of potato-dextrose agar at $25^{\circ} \mathrm{C}$. DNA was extracted from fresh mycelium with a chloroform/octanol mixture (Yli-Mattila et al. 1997) to eliminate proteins, lipids and polysaccharides, which are potential inhibitors of PCR reaction. 
Vol. 6 (1997): 25-36.

Table 1. List of Fusarium isolates. Map numbers refer to the Figure 1.

\begin{tabular}{|c|c|c|c|c|}
\hline $\begin{array}{l}\text { Species } \\
\text { Code } \\
\text { (Isolate }\end{array}$ & $\begin{array}{l}\text { No. } \\
\text { No.*) }\end{array}$ & $\begin{array}{l}\text { Host } \\
\text { (isolated } \\
\text { from) }\end{array}$ & $\begin{array}{l}\text { Geographic } \\
\text { origin } \\
\text { (map number) }\end{array}$ & $\begin{array}{l}\text { Year of } \\
\text { isolation }\end{array}$ \\
\hline \multicolumn{5}{|c|}{ F. avenaceum } \\
\hline 15 & (93015) & barley (stem base) & Apukka (1) & 1992 \\
\hline 28 & (93014) & barley (stem base) & Apukka (1) & 1992 \\
\hline 51 & (92003) & barley (root) & Honkajoki (2) & 1986 \\
\hline 40 & (92004) & barley (root) & Honkajoki (2) & 1986 \\
\hline 14 & (92016) & barley (root) & Kihnio (3) & 1986 \\
\hline 25 & (92006) & barley (root) & Nousiainen (4) & 1986 \\
\hline 17 & (92013) & barley (stem base) & Kankaanpää (5) & 1986 \\
\hline 19 & (92020) & barley (root) & Rautalampi (7) & 1986 \\
\hline 20 & (92024) & barley (root) & Harjavalta (8) & 1986 \\
\hline 47 & (92026) & barley (root) & Leppävirta (9) & 1986 \\
\hline 50 & (92009) & barley (root) & Parkano (10) & 1986 \\
\hline 37 & (92014) & wheat (root) & Janakkala (11) & 1986 \\
\hline 38 & (92015) & wheat (root) & Nummi (12) & 1986 \\
\hline 39 & (93084) & wheat (stem base) & Pälkäne (6) & 1992 \\
\hline 46 & (93071) & wheat (stem base) & Pälkäne (6) & 1992 \\
\hline 26 & (93095) & wheat (stem base) & Kokemäki (13) & 1992 \\
\hline 27 & (93093) & wheat (stem base) & Kokemäki (13) & 1992 \\
\hline 41 & (93088) & wheat (stem base) & Kokemäki (13) & 1992 \\
\hline 42 & (93096) & wheat (stem base) & Kokemäki (13) & 1992 \\
\hline 45 & (93094) & wheat (stem base) & Kokemäki (13) & 1992 \\
\hline 21 & (92005) & wheat (root) & Vihti (14) & 1986 \\
\hline 23 & (92007) & wheat (root) & Karjaa (15) & 1986 \\
\hline 43 & $(93101)$ & oats (stem base) & Kokemäki (13) & 1992 \\
\hline \multicolumn{5}{|c|}{ F. graminearum } \\
\hline 2 & (92029) & barley (root) & Espoo (16) & 1986 \\
\hline \multicolumn{5}{|c|}{ F. culmorum } \\
\hline 35 & (93004) & oats (stem base) & Pälkäne (6) & 1992 \\
\hline \multicolumn{5}{|c|}{ F. equiseti } \\
\hline 9 & (92011) & barley (root) & Kruunupyy (19) & 1986 \\
\hline \multicolumn{5}{|c|}{ F. redolens } \\
\hline 11 & $(93152)$ & barley (root) & Strömfors (18) & 1986 \\
\hline \multicolumn{5}{|c|}{ F. oxysporum } \\
\hline 33 & (93138) & barley (root) & Espoo (16) & 1986 \\
\hline \multicolumn{5}{|c|}{ F. poae } \\
\hline 53 & (93146) & barley (root) & Siuntio (17) & 1985 \\
\hline
\end{tabular}

*Isolate numbers are stock numbers of isolates in the collection of the Agricultural Research Centre of Finland.

\section{Pathogenicity testing}

All $F$, avenaceum isolates except isolate 50 were studied for pathogenicity. They were transferred to $9 \mathrm{~cm}$ plastic petri dishes on potato dextrose agar (PDA, Difco) and incubated for 2 weeks at $18-20^{\circ} \mathrm{C}$ under continuous light to enhance spore production.

The pathogenicity of $F$. avenaceum isolates to potato tubers was tested on cv. Bintje. The tuber material was certified basic seed that had been multiplied from meristem culture for two 


\section{AGRICULTURAL AND FOOD SCIENCE IN FINLAND}

Yli-Mattila, T. et al. UP-PCR analysis of Fusarium avenaceum isolated from wheat and barley

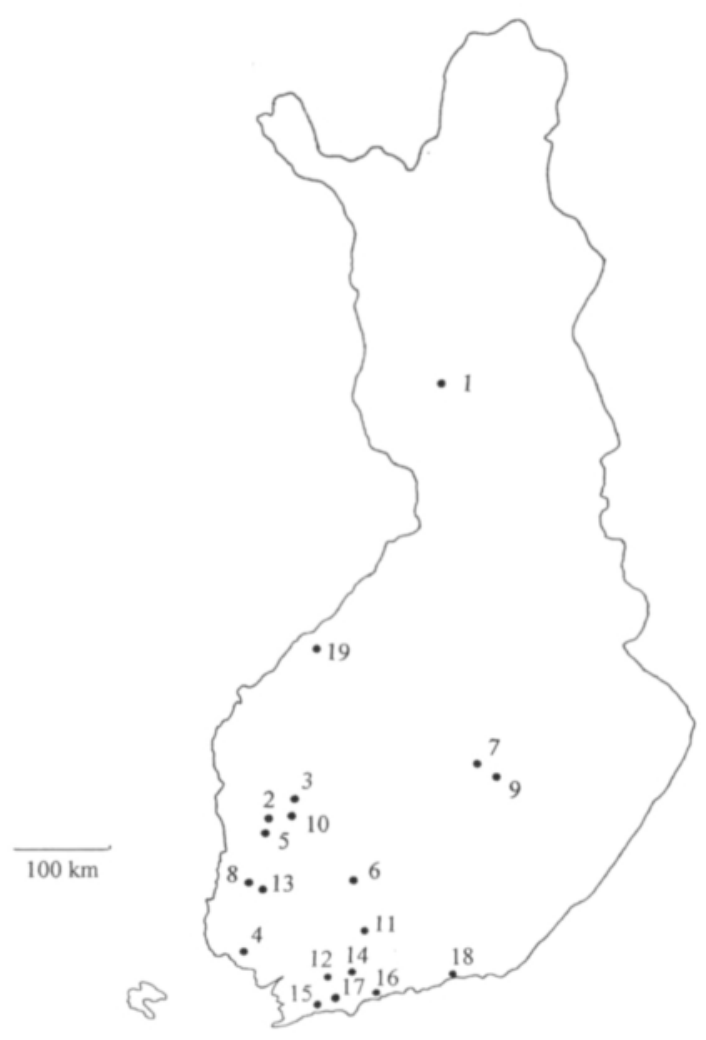

Fig. 1. Geographical origin of Fusarium fungi collected in Finland. Map numbers refer to those given in Table 1.
Pathogenicity to barley and wheat seedlings was studied in a greenhouse test on health-inspected commercial certified seed of barley cv. Pokko and wheat cv. Tapio. Twenty-five seeds were sown in $0.5-1$ plastic pots in sterile sand. The seeds were inoculated by pouring $10 \mathrm{ml}$ of spore suspension of $F$. avenaceum (100000 spores $/ \mathrm{ml}$ ) onto them, after which they were covered with a $2-\mathrm{cm}$ layer of sterile sand. Four replicates of each isolate were inoculated and pots were organized by randomized block design in the greenhouse. Tests on wheat were carried out twice. The plants were grown for 4 weeks at 18 $20^{\circ} \mathrm{C}$ under 12 -h light periods and were then removed carefully from the sand. Stem bases were rated into four categories: $0=$ healthy, $1=$ stem lesions, $2=$ totally brown stem bases and $3=$ dead plants. To compare the pathogenicity of $F$. avenaceum isolates to wheat, barley and potato the different disease ratings of the cereals and potato were scaled to $0-100$. The highest average disease score, 100 was given to the isolate causing the most severe disease symptoms. The average disease scores of other isolates were expressed as percentages of the highest rating.

A simple regression model for pathogenicity of $F$. avenaceum isolates to barley, wheat and potato was calculated using the SAS GLM procedure (Littel et al. 1991).

\section{UP-PCR amplification}

UP-PCR was performed using the thermal cycler TC-1000M (PNPI, St. Petersburg, Russia) for 30 cycles as described by Yli-Mattila et al. (1997). The rate of temperature change was about $4^{\circ} \mathrm{C} \mathrm{s}^{-1}$. The sequences of universal primers designed and synthesized in PNPI were as follows:

\section{3-2 (16 mer) 5'-TGAGGACAACGGTTCC-3' (Bulat et al. 1992)} AA2M2 (16 mer) 5'-GAGCGACCCAGAGCGG-3' (this work) HE 45 (16 mer) 5'-GTAAAACGAGGCCAGT-3' (this work)

Of these, 0.3-2 and AA2M2 primers were used to generate UP-PCR products to be analysed 


\section{AGRICULTURAL AND FOOD SCIENCE IN FINLAND}

Vol. 6 (1997): 25-36.

Table 2. Binary character matrix of $F$. avenaceum isolates analysed by UP-PCR with two universal primers.

\begin{tabular}{|c|c|c|c|c|}
\hline \multicolumn{3}{|c|}{ OTU Primer AA2M2 $\mathrm{Ch}=30+(2)^{* *}$} & \multicolumn{2}{|l|}{ Primer $0.3-2 \mathrm{Ch}=28+(7)^{* *}$} \\
\hline $\mathrm{A}^{*}$ & 000000000000000000000000000000 & & 0000000 & \\
\hline M & & & F $\quad$ E $\quad D$ & \\
\hline 38 & 010000000001011110101100000111 & (01) & 1010110111101000101100000001 & $(0000001)$ \\
\hline 50 & 010000000001011110101100000111 & (01) & 1010110010100100101100000001 & \\
\hline 17 & 000001000001011110101100000111 & (01) & 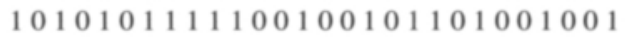 & \\
\hline 19 & 01011110101100000111 & $(00)$ & 111010001010010 & \\
\hline 37 & 001100 & (01) & S & \\
\hline 45 & 0011000 & (01) & 100 & \\
\hline 23 & 001100 & (01) & 100 & \\
\hline 20 & 0011000 & (01) & 00001110 & \\
\hline 26 & 001 & (01) & 0000111010011 & \\
\hline 39 & 0000 & (01) & 10 & \\
\hline 27 & 000 & (01) & 0 & \\
\hline 25 & 006 & $(01)$ & 0 & \\
\hline 40 & 00 & $(01)$ & 0 & \\
\hline 14 & 006 & (01) & 0 & \\
\hline 15 & & (11) & & \\
\hline 47 & 006 & (01) & & \\
\hline 21 & 10 & (01) & & \\
\hline 28 & & (01) & & \\
\hline 46 & & (01) & & ( \\
\hline 41 & & (01) & & ( \\
\hline 2 & 0000 & (01) & 01000011001 & $(00$ \\
\hline 1 & 000010000100010001000000110000 & (01) & 1001101000000101000111001010 & $(0000000)$ \\
\hline
\end{tabular}

OTU - Operative Taxonomic Unit (isolate); $\mathrm{A}^{*}$ - Artificial Ancestor; $\mathrm{Ch}$ - character (only phylogenetically significant and autapomorphic characters shown;

**Number of autapomorphic characters; $\mathrm{M}$ - position of molecular weight markers $(\mathrm{B}-0.25 \mathrm{~kb} ; \mathrm{C}-0.34 \mathrm{~kb} ; \mathrm{D}-0.45 \mathrm{~kb}$; $\mathrm{E}-0.47 \mathrm{~kb} ; \mathrm{F}-0.51 \mathrm{~kb} ; \mathrm{G}-0.80, \mathrm{H}-1.16 \mathrm{~kb}$ ) of Fig. 3.

by gel electrophoresis. The HE 45 primer was used only in dot blot hybridization experiments.

Several amounts $(0.1-1.0 \mu \mathrm{l})$ of template DNA were tested in UP-PCR and run on 1.7\% agarose (Sigma A-7431) gel at $150 \mathrm{~V}$ with cooled TBE buffer to be sure of the reliability of electrophoretic banding profiles. In all cases it was possible to obtain reproducible results on agarose gel by choosing appropriate amounts of template DNA and primer. The efficiency of DNA amplification was also estimated on agarose gel, and equal amounts of the amplification products with the sharpest bands were run on $6 \%$ polyacrylamide gel (thickness $0.8 \mathrm{~mm}$, length $20 \mathrm{~cm}$ ) at $160 \mathrm{~V}$ for $10-14 \mathrm{~h}$ with cold $\left(\mathrm{ca} 12^{\circ} \mathrm{C}\right.$ ) TBE buffer in order to obtain better resolution than with agarose gel. Both agarose and polyacrylamide gels were stained with ethidium bromide and photographed in UV light.

\section{Dot blot hybridization analysis}

Amplification products of three $F$. avenaceum isolates $(17,28$ and 14), which represented the two main groups of RAPD-PCR (Yli-Mattila et al. 1996, Yli-Mattila and Hyvönen 1996) profiles, were compared with those of $F$. graminearum (isolate 2), F. culmorum (isolate 35), $F$. equiseti (isolate 9), $F$. redolens (isolate 11$), F$. oxysporum (isolate 33 ) and $F$. poae (isolate 53) and also with isolate 43 , which, according to 


\section{AGRICULTURAL AND FOOD SCIENCE IN FINLAND}

Yli-Mattila, T. et al. UP-PCR analysis of Fusarium avenaceum isolated from wheat and barley

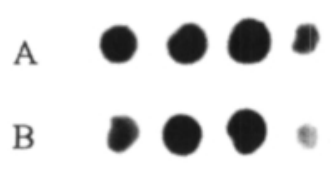

$\begin{array}{llllllllll}17 & 28 & 14 & 43 & 53 & 33 & 11 & 9 & 35 & 2\end{array}$

Fig. 2. Dot blot hybridization of UP-PCR products generated with primers $\mathrm{HE} 45(\mathrm{~A})$ and AA2M2 (B) in $F$. avenaceum (isolates 17, 28, 14 and 43), $F$. poae (isolate 53), $F$. oxysporum (isolate 33 ), $F$. redolens (isolate 11 ), F equiseti (isolate 9), F. culmorum (isolate 35 ) and $F$. graminearum (isolate 2). Dotted samples were hybridized with labelled total UP-PCR products generated with primers HE 45 (A) or AA2M2 (B) for isolate 28.

previous RAPD-PCR and isozyme analyses (YliMattila et al. 1996, Yli-Mattila and Hyvönen 1996), is only distantly related to other $F$. avenaceum isolates.

Total UP-PCR products from all these isolates generated with primers $\mathrm{HE} 45$ and AA2M2 were dotted onto nylon filters (Hybond $\mathrm{N}^{+}, \mathrm{Am}-$ ersham) according to the manufacturer's instructions. The filter-bound fixed PCR products from these isolates were hybridized with the corresponding amplification products of $F$. avenaceum isolate 28, labelled with (alpha- ${ }^{32} \mathrm{P}$ ) dCTP (Izotop, St. Petersburg), at $68^{\circ} \mathrm{C}$ for up to $16 \mathrm{~h}$, as described by Sambrook et al. (1989). The filters were washed and exposed to x-ray film as described by Yli-Mattila et al. (1997).

\section{Data analysis}

The negatives of the polyacrylamide gels were scanned using an original scanning device (V. Zenin, Institute of Cytology, St. Petersburg, Russia) and the images obtained were processed with original image analysis software (N. Klopov, V. Patzekin, PNPI, Russia). High-resolution image analysis allowed us to study all bands in the gel. In this way we could detect weak bands, which are not clearly visible in the photo in Fig. 3. The sizes of the bands were determined according to the peaks of the densitograms of the UP-PCR profiles. All bands detected in image analysis were recorded in a binary matrix irrespective of their intensity.

The data produced by the image analysis (the binary matrix shown in Table 2 and the Dice distance matrix derived from it using the program of N. Klopov, PNPI, Russia) were analysed by the Wagner parsimony (branch and bound algorithm), Neighbor-Joining (NJ) and unweighted pair group method with arithmetic mean (UPGMA) methods of PHYLIP 3.5 (Felsenstein 1993). These analyses included only phylogenetically informative characters, which were present in at least two isolates. To root phylogenetic trees, an Artificial Ancestor (A) taxon (Hennig 1966, Pavlinov 1989) with all characters "0" was invoked.

The reliability of the phylogenetic trees was explored by a bootstrapping procedure using the PHYLIP package. This procedure was adapted for parsimonious trees using SEQBOOT to generate $3 \times 100$ different data sets (jumble options 5,81 and 97 ), which were analysed by the branch and bound method followed by the CONSENSE program. For the UPGMA and NJ methods the same 300 binary data sets were converted to Dice distance ones before analysis by the NEIGHBOR program followed by CONSENSE.

In addition to the branch and bound algorithm, Maximum parsimony analysis was performed with the heuristic search mode of PAUP 3.1 .1 by random addition and tree bisection-reconnection (TBR) swapping and by collapsing zero-length branches (Swofford 1993).

\section{Results}

\section{Dot blot hybridization analysis of Fusarium isolates}

F. avenaceum isolates 17,28 and 14, which were chosen as representatives of all isolates by UPPCR profiles, showed a strong positive signal 


\section{AGRICULTURAL AND FOOD SCIENCE IN FINLAND}

Vol. 6 (1997): 25-36.

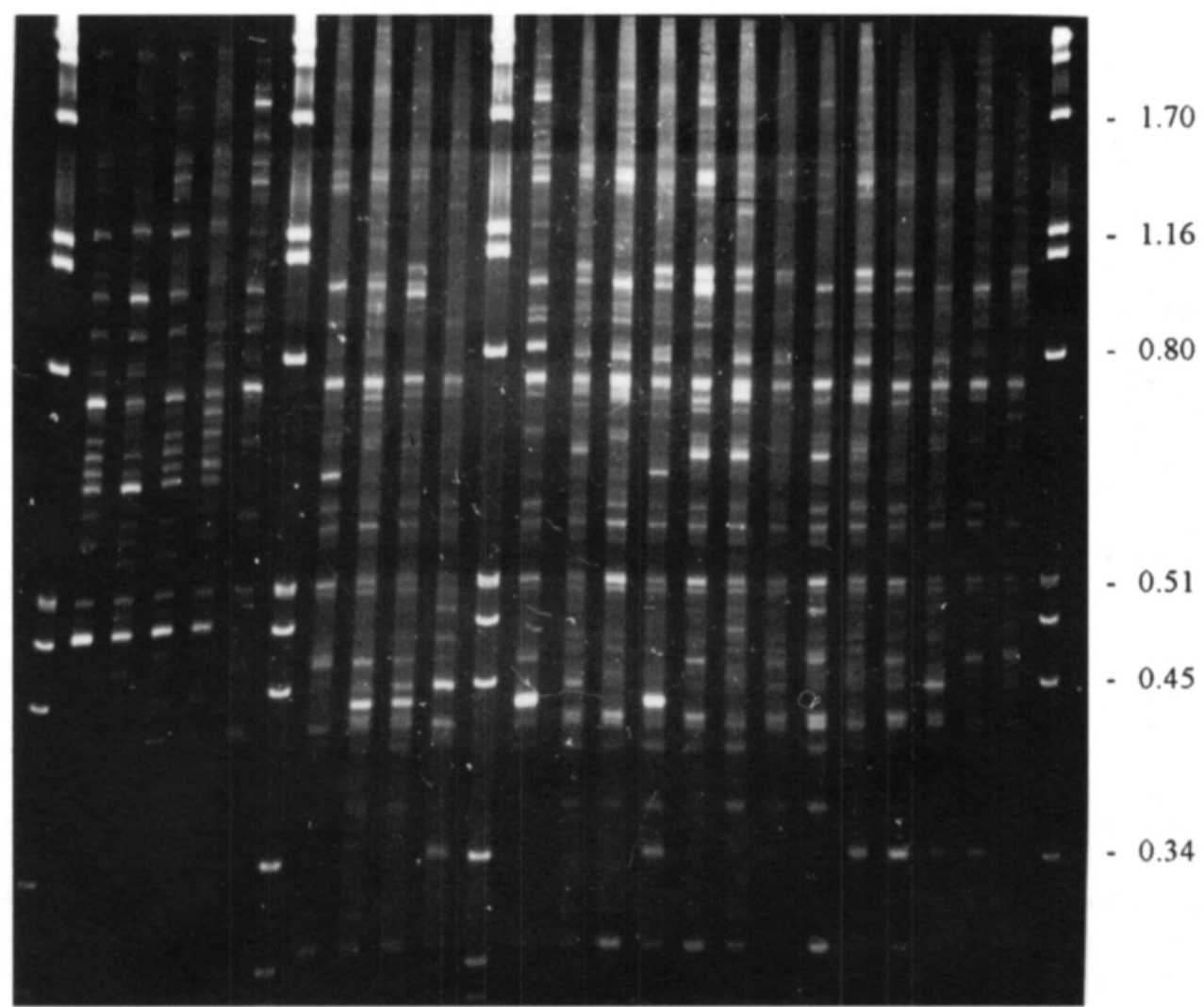

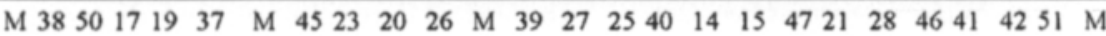

Fig. 3. UP-PCR banding profiles of Fusarium avenaceum isolates with primer 0.3-2. Molecular weight markers (M) lambda DNA digested by Pstl. The sizes $(\mathrm{kb})$ of six molecular weight markers are indicated (modified from the proceedings paper of T. Yli-Mattila et al. 1997).

when UP-PCR products of isolate 28, generated with two UP-PCR primers, were used as a label, whereas amplified DNA from other Fusarium species showed no hybridization (Fig. 2). The hybridization signal from isolate 43 was somewhat weaker than that from other $F$. avenaceum isolates.

\section{UP-PCR analysis of F. avenaceum isolates}

All $F$. avenaceum isolates collected from wheat and barley could be distinguished from each other by the UP-PCR technique using two primers (Fig. 3, Table 2). The primers produced UP-PCR profiles consisting of 7-16 phylogenetic and autapomorphic bands per primer (Table 2). The sizes of bands ranged from 200 to 2000 bp (Fig. 3).

The isolates studied were not derived from single spores, but the clonal origin of four selected isolates of $F$. avenaceum was confirmed by UP-PCR analysis. Single-spore colonies were isolated from original isolates 20, 28, 39 and 51, which were characterized by the most distinguishable UP-PCR patterns on agarose gel. UPPCR products from two single-spore colonies of each of these isolates, together with the original DNA sample, were analysed by polyacrylamide gel electrophoresis. No intrastrain differences were found, and all four isolates could be dis- 


\section{AGRICULTURAL AND FOOD SCIENCE IN FINLAND}

Yli-Mattila, T. et al. UP-PCR analysis of Fusarium avenaceum isolated from wheat and barley

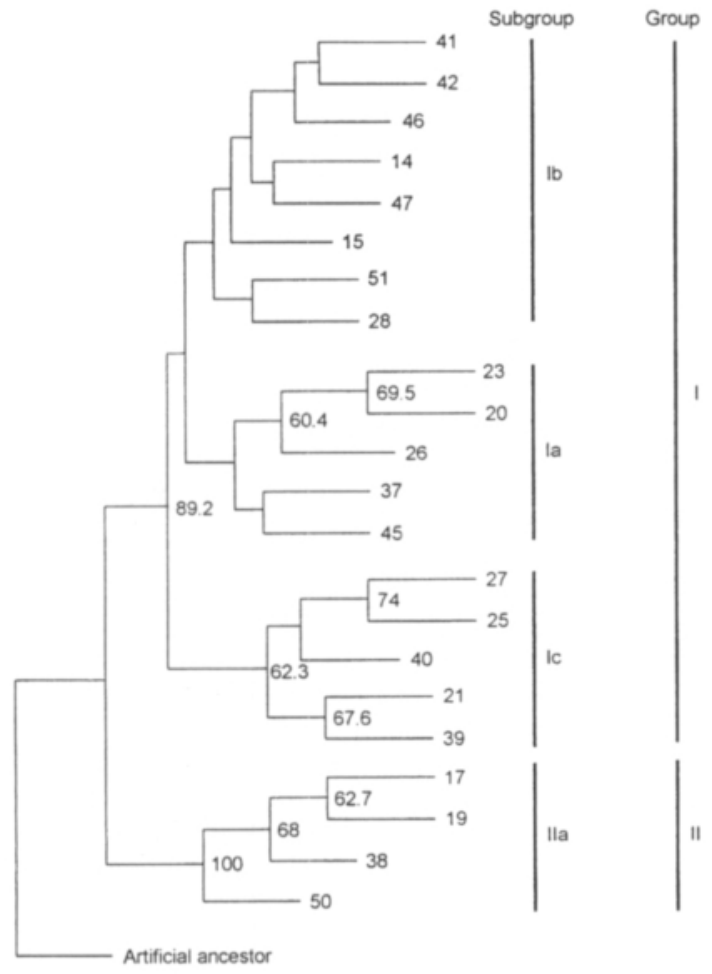

Fig. 4. Phylogenetic relationships among $F$. avenaceum isolates as obtained by Wagner parsimony method of PHYLIP 3.5. Majority rule and strict Wagner consensus tree. Only bootstrap values greater than $50 \%$ are shown.

tinguished from each other (results not shown). Since the isolation methods were the same in all $F$. avenaceum isolates, the rest of the isolates were also probably genetically homogeneous. This is important, because a mixture of genotypes can give confused UP-PCR profiles.

\section{Phylogenetic relationships among $\mathrm{F}$. avenaceum isolates}

In each of the 300 data sets analysed by the branch and bound method, the search broke off when the upper limit was set at 100 or 1000 (the "how many" option), but we succeeded in obtaining 7672 trees characterized by quite different CIs (= consistency index, Felsenstein 1993), including the smallest ones, for each data set. Neither the consensus tree topology nor the bootstrap values actually differed for the two settings (100 and 1000). In addition, the topologies of the Neigbor-Joining and UPGMA consensus trees made of 300 trees (results not shown) were the same as in the Wagner parsimony consensus tree (Fig. 4), allowing us to use these 7672 trees in calculating bootstrap values.

In the Wagner parsimony consensus tree (Fig. 4) of the UP-PCR matrix (Table 2) F. avenaceum isolates could be divided into two main groups with bootstrap values higher than $89 \%$. Group II consisted of isolates 17, 19, 38 and 50. These two groups are also clearly visible in Fig. 3, although group I is fairly heterogeneous. In addition, group I could be divided into three subgroups, of which Ic (isolates 27, 25, 40, 21 and 39) was supported by a bootstrap value higher than $50 \%$.

The $50 \%$ majority rule consensus tree obtained by the heuristic search mode of PAUP 3.1.1 showed a topology identical to the Wagner tree of PHYLIP 3.5 (Fig. 4), except for slight changes in the large subgroup Ib (results not shown). All parsimony and distance methods highlighted subgroup IIa as the most distantly related.

\section{Pathogenicity}

The relative pathogenicity of $F$. avenaceum isolates in wheat was between 42 and 100 , in barley $16-100$ and in potato $63-100$ (Table 3 ). The isolates least pathogenic in wheat were 51 and 25 and the most pathogenic 38, 17, 47 and 14 . In barley the least pathogenic isolates were 40, 25 and 51 and the most pathogenic 38 and 17 ; in potato the least pathogenic isolates were 27,45 and 21 and the most pathogenic 17, 51 and 38 .

The best correlation was found between pathogenicity to wheat and barley (pathogenicity to barley $=11.3+0.55 \mathrm{x}$ pathogenicity to wheat; R-square 0.33, F-value 18.42 and p 0.00012). There was no statistically significant correlation between pathogenicity to barley and potato 
Vol. 6 (1997): 25-36.

Table 3. Relative pathogenicity of $F$. avenaceum isolates to barley, wheat and potato.

\begin{tabular}{lcccc}
\hline Isolate & $\begin{array}{c}\text { Phylogenetic } \\
\text { group }\end{array}$ & Wheat & Barley & Potato \\
\hline 37 & Ia & 74 & 83 & 81 \\
26 & Ia & 82 & 84 & 68 \\
45 & Ia & 80 & 85 & 65 \\
20 & Ia & 89 & 85 & 74 \\
23 & Ia & 87 & 89 & 68 \\
51 & Ib & 42 & 26 & 95 \\
47 & Ib & 95 & 83 & 82 \\
41 & Ib & 87 & 84 & 84 \\
46 & Ib & 75 & 84 & 88 \\
15 & Ib & 84 & 86 & 72 \\
42 & Ib & 71 & 87 & 84 \\
14 & Ib & 91 & 88 & 70 \\
27 & Ic & 84 & 83 & 81 \\
40 & Id & 88 & 16 & 77 \\
25 & Ic & 64 & 21 & 70 \\
27 & Ic & 83 & 86 & 63 \\
21 & Ic & 85 & 87 & 67 \\
39 & Ic & 90 & 88 & 88 \\
19 & IIa & 81 & 80 & 79 \\
17 & IIa & 96 & 90 & 100 \\
38 & IIa & 100 & 100 & 89 \\
\hline & & & & \\
\hline
\end{tabular}

(R-square 0.07 , F-value 3.09, p 0.087) or wheat and potato (R-square 0.12 , F-value 5.27, p 0.027 ), but isolates 17 and 38 were among the 2-3 most pathogenic isolates in all three crops.

\section{Discussion}

All isolates of $F$. avenaceum could be separated into two main groups and distinguished from one another by UP-PCR analysis, which produces more characters per primer than does RAPDPCR (Bulat et al. 1995, Yli-Mattila et al. 1996, Yli-Mattila and Hyvönen 1996). Image analysis of polyacrylamide gel negatives enabled us to clearly separate bands from each other and to compare bands of equal size more accurately than was possible in the previous RAPD-PCR work (Yli-Mattila et al. 1996, Yli-Mattila and
Hyvönen 1996), in which only visual analysis of photos from agarose gel was used.

The UP-PCR products from other Fusarium fungi were completely nonhomologous with those from $F$. avenaceum in the dot blot hybridization analysis, and so we could not infer the phylogeny of $F$. avenaceum isolates from those of other Fusarium species by comparing UPPCR banding profiles. Therefore, in $F$. avenaceum, phylogenetic analyses were performed only on isolates whose UP-PCR products gave a strong hybridization signal showing that these isolates produced homologous bands and indicating that they belonged to the same species (Bulat and Mironenko 1992, Bulat et al. 1995). On these criteria isolate 43 did not belong to $F$. avenaceum and was excluded from UP-PCR analysis.

The phylogenetic analyses of UP-PCR products run on polyacrylamide gel revealed two quite different groups: a large one (I), comprising the majority of isolates, and a smaller one (II), with isolates differing greatly in genome structure from the others. The parsimonious trees obtained for the same $F$. avenaceum isolates with UP-PCR and RAPD data (Yli-Mattila and Hyvönen 1996) were found to be almost the same at main group level. In the RAPD-PCR analysis, group II also included isolate 37 instead of 38 , which constituted its own RAPD group. At subgroup level, the differences between UP-PCR and RAPD-PCR trees were much greater. The resolution and the number of branches with a bootstrap value higher than $50 \%$ were superior in the UP-PCR parsimony tree. However, there were still branches in the UP-PCR parsimony tree with a bootstrap value lower than $50 \%$, which may have been due to the lack of a hierarchic signal within the main groups of isolates collected from a comparatively small area, as was suggested by Yli-Mattila and Hyvönen (1996).

The differences between the trees for UPPCR and RAPD-PCR data are probably due to the fact that the polyacrylamide gel used in the UP-PCR analysis had a better resolution than the agarose gel used in RAPD analysis. Differences in primer sequences and in protocols cannot, 


\section{Yli-Mattila, T. et al. UP-PCR analysis of Fusarium avenaceum isolated from wheat and barley}

however, be excluded. There were also some differences in the algorithms used for phylogeny inference. We are now studying PCR products generated with the same RAPD-PCR primers in a polyacrylamide gel in the hope that we shall be able to compare UP- and RAPD-primer based data with greater accuracy in the future.

The reliability and suitability of RAPD-PCR results for phylogenetic analyses have been questioned, especially above the intraspecific level, due to the uncertain homology of the bands (e.g. Rieseberg 1996), their non-codominant inheritance, asymmetrical transformation features and possible GC priming bias, which altogether make current models of parsimony inappropriate (Backeljeau et al. 1995). In UP-PCR the phylogenetic analysis is performed only at taxon level, where the amplification products are crosshomologous, the primers are not GC-rich and the better resolution obtained by polyacrylamide gel causes fewer errors in finding homologous bands; the two other features of bands (non-codominant inheritance and asymmetrical transformation), however, remain. UP-PCR data may thus be more appropriate for parsimony analysis than RAPD-PCR data. In addition, the parsimony tree of the present study was supported by NJ and UPGMA trees, and previous studies dealing with different fungi (S.A. Bulat, personal communication) show that nearly all bands of UP-PCR profiles are independent of each other and derived from numerous locations dispersed throughout the genome. It should also be noted that it is practically impossible to test all bands in a profile on cross homology by Southern hybridization and that the findings of some studies of phylogenetic relationships based on RAPDPCR or AP-PCR data are in accordance with morphological (Millan et al. 1996) and isozyme (Castagnone-Sereno et al. 1994) results and the history of strains (Canzian et al. 1995).

The use of an artificial ancestor (Hennig 1966, Pavlinov 1989), which is one kind of ingroup comparison, has been criticized (Watrous and Wheeler 1981). It nevertheless offered the only way to calculate all the bootstrap values and still obtain a reasonable tree, since PHYLIP's
CONSENSE program produces trees of different topology when different taxa are allocated as an outgroup. We furthermore found that the Artificial Ancestor created does not affect the branching order of other taxa, since its position has been defined so as to coincide with the midpoint root in a tree.

According to the hybridization analysis performed here and the previous results of RAPDPCR and isozyme studies (Yli-Mattila et al. 1996), isolate 43 is more distantly related to other $F$. avenaceum strains than any other strain under study. Further molecular and morphological studies are required to clarify the status of this isolate and the isolates of group II which differed from all other isolates of $F$. avenaceum. The latest morphological studies (H. Nirenberg, personal communication) have confirmed that the isolates 28 and 37 of group I and the isolate 17 of group II really do belong to $F$. avenaceum, but isolate 43 was identified as $F$. tricinctum. RFLP and sequence analyses of ribosomal DNA in $F$. avenaceum isolates are now in progress.

No clear correlation was found between isolate clustering and their host plant preference or geographic origin, except for two subgroups detected in all trees inferred. In one group (IIa) three of the four isolates (50, 17 and 19) were from barley and in another (Ia) four of the five isolates $(45,37,23$ and 26$)$ were from wheat. Of the five isolates collected from one field at Kokemäki, isolates 41 and 42 were clustered to subgroup $\mathrm{Ib}$ and isolates 45 and 26 to subgroup Ia. The lack of a clear correlation between $F$. avenaceum groups and geographic origin and the host habits of isolates is in agreement with RAPD-PCR and isozyme analyses of the same isolates (Yli-Mattila et al. 1996). This fungus, known as a weak pathogen of cereals and other crops, thus apparently exists under field conditions in the form of numerous vegetative clones and very probably does not evolve in its ability to damage wheat and barley.

Pathogenicity testing of $F$. avenaceum isolates on wheat and barley shows no clear correlation between the $F$. avenaceum isolate grouping and its pathogenicity. Moreover, the most 
Vol. 6 (1997): 25-36.

pathogenic isolates against potato (17 and 51) were positioned quite far from each other in the phylogenetic trees. However, the same two isolates (38 and 17) were among the most pathogenic isolates in wheat and barley, which suggests that the strains of $F$. avenaceum have not specialized for wheat or barley. In addition, it can be noted that these two most pathogenic isolates against wheat and barley belong to the same phylogenetic group (IIa) and that they were also among the most pathogenic isolates against potato.

Acknowledgments. We are grateful to Professor J. Hyvönen (Dept of Plant Ecology and Systematics, University of Turku) for critically reading an earlier version of the manuscript and to G. Häkli for linguistic revision. This investigation was supported by the University of Turku, the Commission for Scientific and Technological Co-Operation between Finland and Russia, The Finnish Academy, and the Russian State Program "Frontiers in Genetics" (in part).

\section{References}

Backeljeau, T., De Bruyn, L., De Wolf, H., Jordaens, K., Van Dongen, S., Verhagen, R. \& Winnepenninckx, B. 1995. Random amplified polymorphic DNA (RAPD) and parsimony methods. Cladistics 11: 119-130.

Booth, C. 1971. The Genus Fusarium. Commonwealth Agricultural Bureaux: Key, Surrey, England. 237 p.

- \& Spooner, B.M. 1984. Gibberella avenacea, teleomorph of Fusarium avenaceum, from stems of Pteridium aquilinum. Transactions of the British Mycological Society 82: 178-180.

Bulat, S.A., Kaboev, O.K., Mironenko, N.V., Ibatullin, F.M., Luchina, L.A. \& Suslov, A.V. 1992. Polymerase Chain Reaction with Universal primers for study of genomes. Soviet Genetics 28: 549-557.

- \& Mironenko, N.V. 1993. Genetic differentiation of phyto-pathogenic fungus Cochliobolus sativus (Ito and Kurib.) Drechsl. ex Dastur (Bipolaris sorokiniana (Sacc.: Sorok.) Shoem.) using the Polymerase Chain Reaction with Universal Primers (UP-PCR): correlation with host specificity. Soviet Genetics 29: 960965.

- , Mironenko, N.V., Lapteva, M.N. \& Strelchenko, P.P. 1994. Polymerase chain reaction with universal primers (UP-PCR) and its application to plant genome analysis. In: Adams, R.P. et al. (eds.) Conservation of Plant Genes II: Utilization of ancient and modern DNA. Vol. 48, Missouri Botanical Garden, St. Louis. p. 113-129.

- , Mironenko, N.V. \& Zholkevich, Yu.G. 1995. Genetic structure of soil population of fungus Fusarium oxysporum Schlechtend.: Fr.: Molecular reidentification of the species and genetic differentiation of isolates using polymerase chain reaction technique with universal primers (UP-PCR). Russian Journal of Genetics 31: 271-278.

Canzian, F., Ushijima, T., Pascale, R., Sugimura, T., Dragani, T.A. \& Nagao, M. 1995. Construction of a phylogenetic tree for inbred strains of rat by arbitrarily primed polymerase chain reaction (AP-PCR). Mammalian genome 6: 231-235.
Castagnone-Sereno, P., Vanlerberghe, F. \& Leroy, F. 1994. Genetic polymorphism between and within Meloidogyne species detected with RAPD markers. Genome 37: 904-909.

Felsenstein, J. 1993. PHYLIP (Phylogeny Inference Package) version 3.5. University of Washington, Seattle, USA.

Gerlach, W. \& Nirenberg, H. 1982. The genus Fusarium - a Pictorial Atlas. Kommissionsverlag Paul Parey, Berlin. 406 p.

Hennig, W. 1966. Phylogenetic systematics. Univ. of Illinois Press, Urbana. $251 \mathrm{p}$.

Littell, R.,C., Freund, R.J. \& Spector, P.C. 1991. SAS system for linear models. Third edition, Cary, NC:SAS Institute Inc. 329 p.

Măkelă, K. \& Parikka, P. 1980. Root and foot rot disease disease of cereals in Southern Finland in 1975-1978. Annales Agriculturae Fenniae 19: 223-253.

Millan, T., Osuna, F., Cobos, S., Torres, A.M. \& Cubero, J.I. 1996. Using RAPDs to study phylogenetic relationships in Rosa. Theoretical and Applied Genetics 92: 273-277.

Naumov, G.I., Naumova, E.S., Kondratieva, V.I., Bulat, S.A., Mironenko, N.V., Mendonca-Hagler, L.C. \& Hagler, A.N. 1997. Systematic and Applied Microbiology 20: 50-56.

Nicholson, P., Jenkinson, P., Rezanoor, H.N. \& Parry, D.W. 1993. Restriction fragment length polymorphism analysis of variation in Fusarium species causing ear blight on cereals. Plant Pathology 42: 905-914.

Pavlinov, I.Ya. 1989. Methods in Cladistics. Moscow State Univ. Press, Moscow. 118 p.

Rieseberg, L.H. 1996. Homology among RAPD fragments in interspecific comparisons. Molecular Ecology 5 : 99-105.

Sambrook, J., Fritsch, E.F. \& Maniatis, T. 1989. Molecular cloning: a Laboratory Manual. 2nd edn. Cold Spring Harbor Laboratory Press, New York.

Seppănen E. 1981a. Fusariums of the potato in Finland I. On the Fusarium species causing dry rot in pota- 


\section{AGRICULTURAL AND FOOD SCIENCE IN FINLAND}

Yli-Mattila, T. et al. UP-PCR analysis of Fusarium avenaceum isolated from wheat and barley

toes. Annales Agriculturae Fenniae 20: 156-160.

- 1981b. Fusariums of the potato in Finland II. On the growth optima of Fusarium species in tubers of Cv. Bintje. Annales Agriculturae Fenniae 20: 161-176.

Swofford, D.L. 1993. PAUP: Phylogenetic analysis using parsimony. Version 3.1.1. Illinois Natural History Survey, Champaign, USA.

Uoti, J. 1976. The effect of five Fusarium species on the growth and development of spring wheat and barley. Annales Agriculturae Fenniae 15: 254-262.

Watrous, L.E. \& Wheeler, Q.D. 1981. The out-group comparison method of character analysis. Systematic Zoology 30: 1-11.

Welsh, J. \& McClelland, M. 1990. Fingerprinting genomes using PCR with arbitrary primers. Nucleic Acids Research 18: 7213-7218.

Williams, J.G.K., Kubelik, A.R., Livak, K.J., Rafalski, J.A. \& Tingey, S.V. 1990. DNA polymorphisms amplified by arbitrary primers are useful as genetic markers. Nucleic Acids Research 18: 6531-6535.
Yli-Mattila, T. \& Hyvönen, J. 1996. RAPD-PCR analysis of Fusarium strains - cladistic evaluation of the results. Sydowia 48: 184-195.

- , Mironenko, N.V., Alekhina, I.A., Hannukkala, A., Hyvőnen, J. \& Bulat, S.A. 1997. Identification of Fusarium avenaceum isolates by RAPD-PCR and UP-PCR. Proceedings of COST 823 Workshop Advances in the Detection of Plant Pathogens by Polymerase Chain Reaction, Ceske Budejovice, June 20-21, 1996. (in press).

- , Paavanen, S., Hannukkala, A., Parikka, P., Tahvonen, R. \& Karjalainen, R. 1996. Isozyme and RAPD-PCR analysis of Fusarium avenaceum isolates from Finland. Plant Pathology 45: 126- 134 .

Ylimăki, A. 1981. The mycoflora of cereal seeds and some feedstuffs. Annales Agriculturae Fenniae 20: 74-88.

- \& Jamalainen, E.A. 1986. The occurrence of Fusarium fungi in Finland. Annales Agriculturae Fenniae 25: 9-30.

\section{SELOSTUS}

\section{Vehnästä ja ohrasta eristettyjen F. avenaceum -punahomekantojen analysointi UP-PCR- menetelmällä}

Tapani Yli-Mattila, Nina V. Mironenko, Irina A. Alekhina, Asko Hannukkala ja Sergey A. Bulat Turun yliopisto, All-Russian Plant Protection Institute, Komarov Botanical Institute, Maatalouden tutkimuskeskus ja Petersburg Nuclear Physics Institute

Suomalaisia vehnästä ja ohrasta eristettyjä punahomekantoja (Fusarium avenaceum) tutkittiin UP-PCR (Universally Primed Polymerase Chain Reaction) -menetelmällä. $F$. avenaceum -kannat voitiin jakaa erilaisilla feneettisillä ja fylogeneettisillä tietokoneohjelmilla kahteen pääryhmään, jotka vielä jakautuivat useaan alaryhmään. Fylogeneettisten ryhmien ja kantojen maantieteellisen jakauman välillä ei voitu havaita selvää riippuvuutta. Kannat erosivat toisistaan patogeenisuustesteissä, mutta samat ohrasta ja vehnästä eristetyt isolaatit olivat patogeenisimpiä sekä vehnällä että ohralla. Tulosten perusteella vaikuttaa siltä, että $F$. avenaceum, jonka tiedetään olevan suhteellisen heikko patogeeni viljakasveilla, ei ilmeisesti ole erikoistunut kumpaankaan isäntäkasviin. 